\title{
Inclusive Human Resource Management (IHRM) and Innovative Work Behaviour in Telecommunication Industry in Rivers State
}

\begin{abstract}
Article History
Received: 15 December, 2020

Revised: 01 February, 2021

Accepted: 20 February, 2021

Published: 13 March, 2021

Copyright () 2021 Noble Academic Publisher \& Author

\author{
Dr. Edwinah, Amah* \\ Port Harcourt, Nigeria \\ Department of Office \& Information Management (Secretarial Studies), \\ Harcourt, Rivers State, Nigeria
}

Department of Management, Faculty of Management Sciences, University of

Dr. Joy Adanma Mekuri-Ndimele Faculty of Business Studies, Ignatius Ajuru University of Education, Port

Abstract: This study examined Inclusive Human Resource Management (IHRM) and Innovative Work Behaviour in Telecommunication Industry in Rivers State. Two hundred employees from the twenty (20) telecommunications services firms were surveyed. Krejcie and Morgan (1970) sample size determination table employed in the study gave a sample size (S) of one hundred and thirty-two (132). Two null hypotheses were established and a total of one hundred and thirty-two (132) copies of the study instrument were distributed, retrieved and analyzed. The Spearman's Rank order correlation coefficient was employed in the study. The study revealed a significant positive relationship between inclusive human resource management and innovative work behaviour (measured by generating and testing ideas and implementation). As a fall out from the study, it is was concluded that a work ambiance that supports equal opportunities and treatment to all employees is a veritable approach for spurring extra-role behaviors such as the active search, generation, championing and implementation of novel ideas for the growth and success of organization. Thus, it was recommended that telecommunication firms should: Train managers-and hold them accountable - to show that inclusivity is a core competency and identify underrepresented groups' needs, and give them necessary support and resources.
\end{abstract}

Key words: Inclusive Human Resource Management, Innovative Work Behaviour, Generating and Testing of Ideas, Implementation.

\section{Introduction}

It is not out of place to argue that businesses' ability to innovate predicts their survival and the extent to which they will attain superior results. Furthermore, scholars have revealed that when employees engage in innovation processes they become proficient and this also has a ripple effect in their place of work (Johnson et al., 2008; Tidd and Bessant, 2009). These scholars offered that employees who engage in innovative behaviors will most likely enjoy certain innate benefits as reward. This benefits which could range from being recognized to an avenue for bettering their skills, is believed to give workers a sense of control and engagement with their job, which ultimately breeds self and job commitment. This is also in corroboration with some other author's observation that workers who take part in the invention of novel products and/or processes tend to build expertise and expand their capacity thereby enhancing their wellbeing and level of satisfaction with their job (Anderson et al., 2004; Messmann and Mulder, 2011).

More so, a myriad of researchers have made efforts towards identifying the factors that stimulate IWB. In one of such attempts, West and Farr (1989) identified five (5) classifications to include individual factors, organizational and job characteristics, team factors and relationship factors. In another study, two dimensions of organizational justice (i.e. distributive justice and procedural justice) have been observed to impact IWB (Adams, 1965; Thibaut and Walker, 1978). Also, extant literature on psychological contract suggests that what may influence the discretionary behaviour (i.e. IWB) of workers in an organization is the satisfaction of shared contractual commitment/agreement (Rousseau, 1989). Lastly, Hackman and Oldham (1980) in their study regarding the design of jobs, observed that when employees perceive that the design of their job gives them some level of control and autonomy over how they carryout task, they will most likely engage in IWB.

Despite all of these attempts to predict innovative work behaviour, there appears to be no empirical exploration on the relationship between inclusive human resource management (IHRM) and innovative work behaviour (IWB). At the very least, majority of the studies have been geographically limited to other developed climes, with scarcely any in Nigeria, especially in the telecommunication industry in Rivers 
State; this leaves a gap in knowledge. As such this study's point of departure from other studies is to examine the relationship between inclusive human resource management and innovative work behaviour in the telecommunication industry in Rivers State.

Figure 1. Operational framework of inclusive human resource management (IHRM) and Innovative Work Behaviour (IWB)

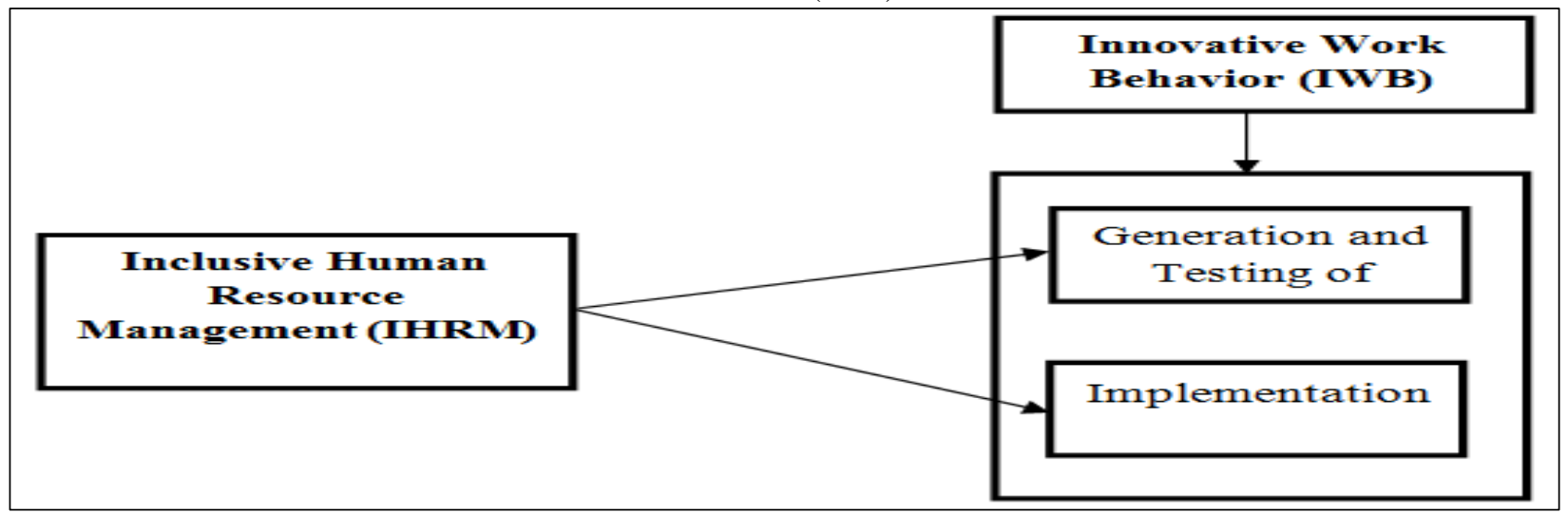

Source: Inclusive human resource management was measured using the instrument from the work of Offermann and Basford (2013); while the measures of Innovative Work Behaviour were adopted from the work of De-Jong and Den (2010).

\section{Hypotheses}

$\mathbf{H}_{01}$ : There is no significant relationship between inclusive human resource management and generating and testing of ideas in the telecommunications industry in Rivers State.

$\mathbf{H}_{\mathbf{0 2}}$ : There is no significant relationship between inclusive human resource management and implementation in the telecommunications industry in Rivers State.

\section{Literature Review}

\subsection{Inclusive Human Resource Management (IHRM)}

In many organizations, inclusion simply means having an equal employment policy tacked to the door or as a section in the staff policy dossier. But inclusion is so much more than the written word. It is the collective of actions, behaviours and gestures that make everyone, no matter what diversity they bring to the table, feel included as part of the bigger collective (Kalra, 2019). The Society for Human Resource Management defines inclusion as "the achievement of a work environment in which all individuals are treated fairly and respectfully, have equal access to opportunities and resources, and can contribute fully to the organisation's success".

According to Hyter and Turnock (2009) in order for an individual to succeed, they must have the opportunity for an observable, and repeatable process of development, success is not an innate ability. Through inclusion, a company can provide all employees with the same opportunities that in bigger organizations could be reserved only for a selected few, and thus maximize the potential and the productivity. Building on the long-term thinking of inclusion, Judith Katz \& Fred Miller, two consultants from the field of diversity management define inclusion as the sense of belonging, feeling respected, valued and seen for who they are as individuals. Inclusion creates a level of supportive energy and commitment from the community in order to gain the full benefit Hanamura (2009).

A clear metaphor in order to define inclusion, created by Hanamura (2009), is to picture an organization working as a choir: all the collaborative relationships in the working community, be it accounting, engineering, HR, administration, global office workers, upper management etc. work together for a common goal. To this end, inclusive human resource management deals with the HR manager ensuring that staff members have a sense of belonging, feel respected, valued and seen for who they are as individuals.

\subsection{Innovative Work Behaviour (IWB)}

Innovative work behavior is repeatedly considered as the foundation of change in the organization as well as innovation in the organization. Scholars have mostly defined IWB as the intentional initiations and efforts led by individual employees to generate new ideas, get support, and implement ideas to 
improve the performance of their tasks (Bagheri and Akbari, 2018; Chen and Leung, 2016). Due to the increased importance of innovation as an important ingredient for organizational success and survival, study of those factors that enhance innovative work behavior has also increased (Widmann and Mulder, 2018).

Whether or not organizations are able to improve their performance by introducing more innovation has been a major topic of study by the researchers and practitioners. Some studies found innovativeness as the important factor helping organizations to have a sustainable competitive advantage over competitors and also as a major contributor to firm's long term success and survival (see: (Akram et al., 2016; Alsughayir, 2017; Kremer et al., 2019). Some concluded that in rapidly changing business world, IWB is considered as an important asset for organizational success.

IWB is not only important for the innovation-oriented organizations or jobs but it is also very important for whole organizational workforce (Hassan et al., 2018). Innovative work behavior is focused on such actions that are initiated by the individuals themselves and their aim is to improve the present conditions originating new ones for the organization and for themselves (Akram et al., 2016; Alsughayir, 2017).

\subsection{Generation and Testing of Ideas}

Girotra et al. (2010) Claim that almost all innovation processes include idea generation and selection of ideas or opportunities. Boeddrich (2004) emphasizes that all innovation is based on an idea that can be inside or outside the company. Verworn (2006) reports that domestic inputs are the main sources of generating ideas, and highlights areas of marketing, sales, senior management and R \& D inputs as great ideas. External sources can happen in the form of participation by customers who have their desires, their needs and to their solutions for possible products. Competitors may also provide new ideas. The knowledge of a competitor's product can instigate a team to create a new product or improve a product already marketed by the company (Cooper and Edgett, 2012). Techniques and tools can be used to help in generating ideas. They increase the number and quality of ideas generated (Mcadam and Mcclelland, 2002). Thus, the generation of ideas is essential in the innovation process, and, according to Miguez (2012), the person responsible for applying a session to generate ideas can, based on his/her experience, choose one of several techniques to be applied according to the profile of the company.

\subsection{Implementation}

The implementation stage is described as a convergent IWB that comprised of two intertwined elements which are championing (idea promotion) and application (idea implementation) efforts. Basically this stage occurs when an organization has decided on an idea. This means the idea will be converted into an actual result with a prior test before launching - which is known as the convergent IWB (De-Jong et al., 2003).

Furthermore, in this stage, it is necessary for knowledge workers need to become more conversant with results in the process of idea development and implementation (Mumford, 2000). When new service has been taken up and established as a status quo among the knowledge workers, the innovation process is said to have come to a conclusion. Thus, given new idea, it has to be developed, tested and commercialized by the knowledge workers. When the knowledge workers have decided to develop, test and commercialize a new service, idea implementation or the application of an idea is taking place (DeJong et al., 2003) and innovation is thus becoming part of the organization working process (Kleysen and Street, 2001).

\section{Theoretical Framework}

\subsection{Social Exchange Theory (SET)}

Blau (1964) proposed the SET based on the norms of the reciprocity theory, which is the origin of SET in a sociological context. SET in the environment of an organization has the principle that employees might feel obliged toward their supervisor, coworker, or organization if they have received any benefit from an exchange with the individual or the organization in the past (Blau, 1964). Two or more people can initiate a social exchange relationship within the organization (Gould-Williams and Davies, 2005). When an individual realizes that other individuals have received more benefits from an exchange and the benefits are not mutually shared within a suitable time, as realized by the individual who contributed the social benefit, it may have a negative impact on the workplace environment and the relations between employees (Cropanzano and Mitchell, 2005; Molm et al., 2007). 
Such types of issues with workplace relationships have been revealed to be a major and significant problem in the organizations, because social exchange is not governed by any rules or regulations; rather, they are dependent on the culture, organization environment, and perception of the individuals involved in the exchange (De-Clercq et al., 2010) which means that every individual involved in the social exchange network will have their own perception-which will be different from others - in terms of what is the fair level of exchange for a positive benefit and what is the right time during which to return these benefits (Dabos and Rousseau, 2004). This theory is considered appropriate in underpinning this study given that employees who perceive that the HR manager is concerned about providing an inclusive working environment for them, would in turn reciprocate with extra role behaviour (i.e innovative work behaviour).

\subsection{Empirical Review}

\begin{tabular}{|c|c|c|c|c|c|}
\hline $\begin{array}{c}\text { S/N } \\
\text { o. }\end{array}$ & Author/Year & Country & Topic/Objective & Method Used & Findings \\
\hline \multicolumn{6}{|c|}{ Empirical Review on Inclusive Human Resource Management (IHRM) } \\
\hline 1. & $\begin{array}{l}\text { Offermann } \\
\text { and Basford } \\
(2013)\end{array}$ & U.S.A & $\begin{array}{l}\text { Examining how } \\
\text { diversity and inclusion } \\
\text { are currently practiced. }\end{array}$ & $\begin{array}{lr}\text { Sample of leading } \\
\text { corporations } \\
\text { recognized for their } \\
\text { excellence } \\
\text { managing in } \\
\text { workforces. }\end{array}$ & $\begin{array}{l}\text { To advance } \\
\text { diversity and } \\
\text { inclusion in the } \\
\text { workplace, HR } \\
\text { must carefully } \\
\text { attend to both } \\
\text { structural and } \\
\text { cultural elements } \\
\text { of the organization. }\end{array}$ \\
\hline 2. & $\begin{array}{c}\text { Borghouts-van } \\
\text { de and Freese } \\
\text { (2017) }\end{array}$ & Netherland & $\begin{array}{l}\text { Inclusive HRM and } \\
\text { Employment } \\
\text { Security for Disabled } \\
\text { People: } \\
\text { An Interdisciplinary } \\
\text { Approach }\end{array}$ & $\begin{array}{l}\text { Combined insights } \\
\text { from Social Policy and } \\
\text { HRM literature and } \\
\text { discuss several factors } \\
\text { that play a role in the } \\
\text { process of (not) } \\
\text { offering jobs to } \\
\text { disabled people. As } \\
\text { well as a conceptual } \\
\text { strategic inclusive HR } \\
\text { model. }\end{array}$ & $\begin{array}{l}\text { Different } \\
\text { perspectives, } \\
\text { focusing } \\
\text { economic } \\
\text { rationality, } \\
\text { wellbeing, social } \\
\text { legitimacy, may } \\
\text { lead to different } \\
\text { hiring strategies. }\end{array}$ \\
\hline 3. & $\begin{array}{c}\text { Vesalainen } \\
\text { (2017) }\end{array}$ & Finland & $\begin{array}{l}\text { Workplace Inclusion } \\
\text { and Exclusion in } \\
\text { Finnish-based Small } \\
\text { and Medium sized } \\
\text { Enterprises }\end{array}$ & $\begin{array}{l}\text { The collection method } \\
\text { of the data was based } \\
\text { on semi-structured } \\
\text { interviews to which } 6 \\
\text { respondents from } 4 \\
\text { different companies } \\
\text { were approached with } \\
\text { the aim of discovering } \\
\text { how the phenomena } \\
\text { occurred in the Small } \\
\text { and Medium sized } \\
\text { Finnish-based } \\
\text { companies } \\
\text { worked in. }\end{array}$ & $\begin{array}{l}\text { Companies that } \\
\text { had succeeded in } \\
\text { creating clear ways } \\
\text { for communication } \\
\text { and had set clear } \\
\text { practices } \\
\text { managing their } \\
\text { human } \\
\text { through } \\
\text { recruitment } \\
\text { employee } \\
\text { development had } \\
\text { better } \\
\text { sustainably: results } \\
\text { turnover low } \\
\text { employees leaving } \\
\text { the company, as } \\
\text { well as lesser cases } \\
\text { of workplace- } \\
\text { bullying on } \\
\text { conflicts due to } \\
\text { misunderstandings. }\end{array}$ \\
\hline \multicolumn{6}{|c|}{ Empirical Review on Innovative Work Behaviour (IWB) } \\
\hline
\end{tabular}




\begin{tabular}{|c|c|c|c|c|c|}
\hline 4. & $\begin{array}{l}\text { Haider and } \\
\text { Feng (2016) }\end{array}$ & China & $\begin{array}{l}\text { To explored the impact } \\
\text { of organizational justice } \\
\text { in the form of } \\
\text { distributive, procedural, } \\
\text { interactional, temporal } \\
\text { and spatial justice on } \\
\text { the IWB of the } \\
\text { employees working in } \\
\text { the telecommunication } \\
\text { sector in China. }\end{array}$ & $\begin{array}{lrr}\text { Data } & \text { was } & \text { collected } \\
\text { from } & 235 & \text { employees } \\
\text { and analyzed by using } \\
\text { correlation } & \text { and } \\
\text { multiple } & \text { regression } \\
\text { analysis. } & \end{array}$ & $\begin{array}{l}\text { The results of these } \\
\text { analyses suggested } \\
\text { that all forms of } \\
\text { organizational } \\
\text { justice have a } \\
\text { strong and positive } \\
\text { impact on the IWB } \\
\text { of the Chinese } \\
\text { employees, } \\
\text { particularly, spatial } \\
\text { and temporal } \\
\text { justice were found } \\
\text { explaining highest } \\
\text { variance in IWB of } \\
\text { employees } \\
\text { respectively. }\end{array}$ \\
\hline 5. & $\begin{array}{l}\text { Ruhnke and } \\
\text { Mulder (2010) }\end{array}$ & Germany & $\begin{array}{l}\text { To examine the specific } \\
\text { relationship between } \\
\text { both opening and } \\
\text { closing leadership } \\
\text { behaviour and the four } \\
\text { different aspects of } \\
\text { IWB. }\end{array}$ & Regression analysis. & $\begin{array}{l}\text { The result showed } \\
\text { that the interaction } \\
\text { between closing } \\
\text { and } \\
\text { leadership } \\
\text { behaviour } \\
\text { positively related } \\
\text { to IWB. }\end{array}$ \\
\hline 6. & $\begin{array}{l}\text { Bysted and } \\
\text { Jespersen } \\
\text { (2014) }\end{array}$ & Scandinavia & $\begin{array}{l}\text { To investigate the } \\
\text { effectiveness } \\
\text { managerial mechanisms } \\
\text { in a public versus } \\
\text { private context. }\end{array}$ & $\begin{array}{l}\text { Regression models for } \\
\text { differences } \\
\text { effectiveness. }\end{array}$ & $\begin{array}{l}\text { From the results, } \\
\text { two distinct } \\
\text { perceptions } \\
\text { emerged: Public } \\
\text { employees perceive } \\
\text { IWB as extra-role } \\
\text { behaviour to be } \\
\text { compensated for. } \\
\text { Private employees } \\
\text { recognize IWB as } \\
\text { necessary } \\
\text { behaviour for } \\
\text { career } \\
\text { advancement. }\end{array}$ \\
\hline 7. & $\begin{array}{l}\text { Radaelli et al. } \\
\text { (2011) }\end{array}$ & Italy & $\begin{array}{l}\text { Knowledge sharing and } \\
\text { IWB in Healthcare } \\
\text { Industry. }\end{array}$ & $\begin{array}{l}\text { Tested hypotheses on } \\
155 \text { employees in four } \\
\text { palliative care } \\
\text { organizations. }\end{array}$ & $\begin{array}{lr}\text { Their results } \\
\text { provided original } \\
\text { evidence that } \\
\text { employees who } \\
\text { share knowledge } \\
\text { also engage more } \\
\text { in creating, } \\
\text { promoting and } \\
\text { implementing } \\
\text { innovations. }\end{array}$ \\
\hline 8. & $\begin{array}{l}\text { Ong } \\
(2003)\end{array}$ & Singapore & $\begin{array}{lr}\text { Identifying } & \text { those } \\
\text { internal and } & \text { external } \\
\text { organizational } & \\
\text { characteristics } & \text { that } \\
\text { significantly affect } \\
\text { individual innovation in } \\
\text { an organization. }\end{array}$ & $\begin{array}{l}\text { A sample of } 190 ; \\
\text { made up of } 34,54 \text { and } \\
102 \text { top, middle } \\
\text { operational } \\
\begin{array}{l}\text { employees, } \\
\text { respectively, } \\
\text { obtained. }\end{array} \\
\end{array}$ & $\begin{array}{l}\text { Results from the } \\
\text { study showed that } \\
\text { individual } \\
\text { innovation does not } \\
\text { significantly differ } \\
\text { across the three } \\
\text { levels of } \\
\text { employees. }\end{array}$ \\
\hline
\end{tabular}

\section{Methodology}

The theoretical population for this study involves all the staff of the one hundred and eighty-seven (187) telecommunication services firms in Rivers State. However, the accessible population for the study comprise of staff of twenty (20) telecommunications services firms in the state, hinged on the researcher's convenience and accessibility. The sampling frame was derived from a specialized list of businesses in 
Rivers State Yellow Pages Directory (2013-2014 ed.). From the state's official business directory, the total number of telecommunications services firms is one hundred and eighty-seven (187). Two hundred employees from the twenty (20) telecommunications services firms were surveyed. Krejcie and Morgan (1970) sample size determination table employed in the study gave a sample size $(S)$ of one hundred and thirty-two (132). To give each respondent an equal chance of being selected, the simple random sampling technique was used. Given the study context, all items were pre-tested to ensure its consistency in measuring the constructs. The instrument satisfied Nunnally and Bernstein (1994) 0.7 minimum thresholds, with a Cronbach Alpha and composite reliability value of .798. Data for the study was collected and analyzed by means of the Spearman's Rank Order Correlation Coefficient (Rho), using the Statistical Package for Social Science (SPSS).

\section{Results and Discussion}

\subsection{Test of Hypotheses}

This section is concerned with testing hypotheses stated earlier in chapter one; using Spearman's rank order correlation coefficient statistical tool and the p-values obtained.

Decision Rule: reject null hypothesis if p-value obtained is less than the alpha value $(0.05 / 95 \%$ level of significance) and accept null hypotheses when p-value is greater than the alpha value.

Table 4.1. Test of relationship between inclusive human resource management and generating and testing of ideas (H01)

\begin{tabular}{|c|c|c|c|c|}
\hline & & & $\begin{array}{c}\text { Inclusive Human } \\
\text { Resource } \\
\text { Management } \\
\end{array}$ & $\begin{array}{l}\text { Generating and } \\
\text { Testing of Ideas }\end{array}$ \\
\hline \multirow{6}{*}{ Spearman's rho } & \multirow{3}{*}{$\begin{array}{ll}\text { Inclusive Human } \\
\text { Resource } \\
\text { Management }\end{array}$} & Correlation Coefficient & 1.000 & $.865^{* *}$ \\
\hline & & Sig. (2-tailed) & & .000 \\
\hline & & $\mathrm{N}$ & 132 & 132 \\
\hline & \multirow{3}{*}{$\begin{array}{ll}\text { Generating } & \text { and } \\
\text { Testing of Ideas } & \end{array}$} & Correlation Coefficient & $.865^{* * *}$ & 1.000 \\
\hline & & Sig. (2-tailed) & .000 &. \\
\hline & & $\mathrm{N}$ & 132 & 132 \\
\hline
\end{tabular}

**. Correlation is significant at the 0.05 level (2-tailed).

Source: SPSS output, Version 20 - Field Survey, 2019

Table 4.1 shows Spearman's rho correlation analysis to find out the relationship between inclusive human resource management and generating and testing of ideas among one hundred and thirty-two (132) participants. A strong positive correlation coefficient value was reported between variables which is statistically significant ( $\mathrm{rho}=.865^{* *}, \mathrm{p}=.000<0.05$ (alpha value).

Decision: Hence; we reject the null hypothesis $\left(\mathrm{HO}_{1}\right)$ that states that there is no significant relationship between inclusive human resource management and generating and testing of ideas in the telecommunications industry in Rivers State and we accept the alternate; there is significant relationship between inclusive human resource management and generating and testing of ideas in the telecommunications industry in Rivers State $\left(\mathrm{HA}_{1}\right)$.

Table 4.2. Test of relationship between inclusive human resource management and implementation $\left(\mathbf{H} \mathbf{0}_{2}\right)$

\begin{tabular}{|c|c|c|c|c|}
\hline & & & $\begin{array}{c}\text { Inclusive Human } \\
\text { Resource } \\
\text { Management }\end{array}$ & Implementation \\
\hline \multirow{6}{*}{ Spearman's rho } & \multirow{3}{*}{$\begin{array}{ll}\text { Inclusive } & \text { Human } \\
\text { Resource } & \\
\text { Management } & \\
\end{array}$} & Correlation Coefficient & 1.000 & $.945^{* *}$ \\
\hline & & Sig. (2-tailed) & 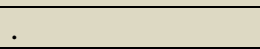 & .000 \\
\hline & & $\mathrm{N}$ & 132 & 132 \\
\hline & \multirow[t]{3}{*}{ Implementation } & Correlation Coefficient & $.945^{* *}$ & 1.000 \\
\hline & & Sig. (2-tailed) & .000 & . \\
\hline & & $\mathrm{N}$ & 132 & 132 \\
\hline
\end{tabular}

**. Correlation is significant at the 0.05evel (2-tailed).

Source: SPSS output, Version 20 - Field Survey, 2019

Table 4.2 shows Spearman's rho correlation analysis to find out the relationship between inclusive human resource management and generating and testing of ideas in the telecommunications industry in Rivers State among one hundred and thirty-two (132) participants. A strong positive correlation coefficient value was reported between variables which is statistically significant (rho $=.945^{* *}, \mathrm{p}=.000<$ 0.05 (alpha value). 
Decision: Hence; we reject the null hypothesis $\left(\mathrm{HO}_{2}\right)$ that states that there is no significant relationship between inclusive human resource management and generating and testing of ideas in the telecommunications industry in Rivers State and we accept the alternate; there is significant relationship between inclusive human resource management and generating and testing of ideas in the telecommunications industry in Rivers State $\left(\mathrm{HA}_{2}\right)$.

\subsection{Discussion of Findings}

The study examined the relationship between inclusive human resource management and innovative work behaviour in the telecommunications industry in Rivers State; two hypotheses were formulated and the results of the tested null hypotheses revealed the existent of a significant relationship between inclusive human resource management and innovative work behaviour (measured by generating and testing of ideas and implementation). This finding is in congruence with several scholarly postulations on the relationship between the variables. For instance, it has been revealed that to handle complex process of IWB, employees seek a sought of psychological empowerment to engage in IWB (Afsar and Badir, 2016; Knol and Van-Linge, 2009). This is because through psychological empowerment, employees experienced autonomy, meanings, competencies and feedback to showcase IWB (Battistelli et al., 2013; Ertürk, 2012; Orth and Volmer, 2017).

Also, research on cognitive evaluation theory (CET) suggested that it was in fact intrinsic motivation (in this case psychological empowerment) that allowed individuals to feel autonomy, competency, meaning and feedback in their work which in turn affected their IWB (Javed et al., 2017; Yidong and Xinxin, 2013). CET framework explained that employees evaluated the external factors to behave in a certain way, while similar in the milieu of innovation, where employees evaluated the external context to find support for their IWB. According to Yidong and Xinxin (2013), if employees found supportive ambiance, then they felt great motivation to show IWB.

\section{Conclusion and Recommendation}

As a fall out from the study, it is not out of place to conclude that a work ambiance that supports equal opportunities and treatment to all employees is a veritable approach for spurring extra-role behaviours such as the active search, generation, championing and implementation of novel ideas for the growth and success of organization. Thus, it is recommended that telecommunication firms should:

i. Train managers - and hold them accountable - to show that inclusivity is a core competency.

ii. Identify underrepresented groups' needs, and give them necessary support and resources.

\section{References}

Adams, J. S. (1965). Inequity in social exchange. Advances in Experimental Social Psychology, 2(1): 26799.

Afsar, B. and Badir, Y. F. (2016). Person-organization fit, perceived organizational support, and organizational citizenship behavior: The role of job embeddedness. Journal of Human Resources in Hospitality \& Tourism, 15(3): 252-78.

Akram, T., Leia, S. and Haidera, M. J. (2016). The impact of relational leadership on employee innovative work behavior in IT industry of China. Arab Economic and Business Journal, 11(2): 153-61.

Alsughayir, A. (2017). The effect of leader-member exchange on innovative work behavior in the Saudi hospitality. International Journal of Business and Management, 12(6): 189-95.

Anderson, N. R., De-Dreu, C. K. W. and Nijstad, B. A. (2004). The routinization of innovation research: A constructively critical review of the state-of-the-science. Journal of Organizational Behavior, 25(2): 147-73.

Bagheri, A. and Akbari, M. (2018). The impact of entrepreneurial leadership on nurses' innovation behavior. Journal of Nursing Scholarship, 50(1): 28-35.

Battistelli, A., Montani, F. and Odoardi, C. (2013). The impact of feedback from job and task autonomy in the relationship between dispositional resistance to change and innovative work behaviour. European Journal of Work and Organizational Psychology, 22(1): 26-41.

Blau, P. M. (1964). Justice in social exchange. Sociological Inquiry, 34(2): 193-206.

Boeddrich, H. J. (2004). Ideas in the workplace: A new approach towards organizing the fuzzy front end of the innovation process. Creativity and Innovation Management, 13(4): 274-85.

Borghouts-van de, P. I. and Freese, C. (2017). Inclusive HRM and employment security for disabled people: An interdisciplinary approach. E-Journal of International and Comparative Labour Studies, 6(1): 9-33. 
Bysted, R. and Jespersen, K. R. (2014). Exploring managerial mechanisms that influence innovative work behaviour: Comparing private and public employees. Public Management Review, 16(2): 217-41.

Chen, L. T. and Leung, K. (2016). When does supervisor support encourage innovative behavior? Opposite moderating effects of general self-efficacy and internal locus of control. Personnel Psychology, 69(1): 123-58.

Cooper, R. G. and Edgett, S. J. (2012). Ideation for Product Innovation: What are the best methods? Product Development Institute, Canada.

Cropanzano, R. and Mitchell, M. S. (2005). Social exchange theory: An interdisciplinary review. Journal of Management, 31(6): 874-900.

Dabos, G. E. and Rousseau, D. M. (2004). Mutuality and reciprocity in the psychological contracts of employees and employers. Journal of Applied Psychology, 89(1): 52-72.

De-Clercq, D., Dimov, D. and Thongpapanl, N. T. (2010). The moderating impact of internal social exchange processes on the entrepreneurial orientation-performance relationship. Journal of Business Ventures, 25(1): 87-103.

De-Jong, J. and Den, H. D. (2010). Measuring innovative work behaviour. Creativity and Innovation Management, 19(1): 23-36.

De-Jong, J., Den, H. D. and Zoetermeer. (2003). Leadership as determinant of innovative behavior: A conceptual framework. Research Report H200303, . 1-95.

Ertürk, A. (2012). Linking psychological empowerment to innovation capability: Investigating the moderating effect of supervisory trust. International Journal of Business and Social Science, 3(14): 153-65.

Girotra, K., Terwiesch, C. and Ulrich, K. T. (2010). Idea generation and the quality of the best idea. Management Science, 56(4): 591-605.

Gould-Williams, J. and Davies, F. (2005). Using social exchange theory to predict the effects of HRM practice on employee outcomes: An analysis of public sector workers. Public Management Review, 7(1): 1-24.

Hackman, J. R. and Oldham, G. R. (1980). Work redesign. Reading. MA: Addison-Wesley.

Haider, M. J. and Feng, X. Y. (2016). The effects of organizational justice on the innovative work behavior of employees: An empirical study in China. Journal of Creativity and Business Innovation, 2(1): 114-26.

Hanamura, S. (2009). Creating and maintaining an inclusive workforce: Workforce diversity network. Available http://www.workforcediversitynetwork.com/docs/Articles/Article CreatingMaintainingInclusive Workforce_Hanamura 4.09.pdf.

Hassan, H. A., Asif, J., Waqar, N., Khalid, S. and Abbas, S. K. (2018). The impact of knowledge sharing on innovative work behavior. Asian Journal of Multidisciplinary Studies, 6(5): 22-25.

Hyter, M. C. and Turnock, J. L. (2009). The power of inclusion: Unlock the potential and productivity of your workforce. John Wiley \& Sons.

Javed, B., Khan, A. A., Bashir, S. and Arjoon, S. (2017). Impact of ethical leadership on creativity: The role of psychological empowerment. Current Issues in Tourism, 20(8): 839-51.

Johnson, M. W., Christensen, M. C. and Kagermann, H. (2008). Reinventing your business model. Harvard Business Review, 86(12): 50-59.

Kalra, A. S. (2019). What inclusion in the workplace is (and isn't). Retrieved from https://www.humanresourcesonline.net/what-inclusion-in-the-workplace-is-and-isnt/.

Kleysen, R. and Street, C. (2001). Toward a multi-dimensional measure of individual innovative behavior. Journal of Intellectual Capital, 2: 284-96.

Knol, J. and Van-Linge, R. (2009). Innovative behaviour: The effect of structural and psychological empowerment on nurses. Journal of Advanced Nursing, 65(2): 359-70.

Krejcie, R. V. and Morgan, D. W. (1970). Determining sample size for research activities. Educational and Psychological Measurement, 30(3): 607-10.

Kremer, H., Villamor, I. and Aguinis, H. (2019). Innovation leadership: Best-practice recommendations for promoting employee creativity, voice, and knowledge sharing. Business Horizons, 62(1): 6574.

Mcadam, R. and Mcclelland, J. (2002). Individual and team-based idea generation within innovation management: Organizational and research agendas. European Journal of Innovation Management, 5(2): 86-97.

Messmann, G. and Mulder, R. H. (2011). Innovative work behaviour in vocational colleges: Understanding how and why innovations are developed. Vocations and Learning, 4(1): 63-84. 
Miguez, V. B. (2012). Uma abordagem de geração de ideias para o processo de inovação. (Dissertacao de Mestrado em Engenharia e Gestao do Conhecimento, Programa de Pos Graduacao em Engenharia e Gestao do Conhecimento, Universidade Federal de Santa Catarina).

Molm, L. D., Collett, J. L. and Schaefer, D. R. (2007). Building solidarity through generalized exchange: A theory of reciprocity. American Journal of Sociology, 13(1): 205-42.

Mumford, M. D. (2000). Managing creative people: strategies and tactics for innovation. Human Resource Management Review, 10: 313-51.

Nunnally, J. C. and Bernstein, I. H. (1994). Psychometric theory (3rd ed.). New York: McGraw-Hill.

Offermann, L. R. and Basford, T. E. (2013). Inclusive human resource management: Best practices and the changing role of human resources. Diversity at work: The practice of inclusion. 229-59.

Ong, C. H., Wan, D. and Chng, S. H. (2003). Factors affecting individual innovation: An examination within a Japanese subsidiary in Singapore. Technovation, 23(7): 617-31.

Orth, M. and Volmer, J. (2017). Daily within-person effects of job autonomy and work engagement on innovative behaviour: The cross-level moderating role of creative self-efficacy. European Journal of Work and Organizational Psychology, 26(4): 601-12.

Radaelli, G., Mura, M., Spiller, N. and Lettieri, E. (2011). Intellectual capital and knowledge sharing: The mediating role of organisational knowledge-sharing climate knowledge. Management Research and Practice, 7(4): 365-76.

Rousseau, D. M. (1989). Psychological and implied contracts in organizations. Employee Responsibilities and Rights Journal, 2(2): 121-39.

Ruhnke, M. and Mulder, R. H. (2010). Ambidextrous leadership and innovative work behavior. University of Regensburg, Institute of Educational Science.

Thibaut, J. W. and Walker, L. (1978). A theory of procedure. California Law Review, 66(1): 541-66.

Tidd, J. and Bessant, J. (2009). Managing innovation: Integrating technological, market and organizational change. Chichester: Wiley.

Verworn, B. (2006). How German measurement and control firms integrate market and technological knowledge into the front end of new product development. International Journal of Technology Management, 34(3): 379-89.

Vesalainen, V. E. (2017). Workplace inclusion and exclusion in Finnish-based small and medium sized enterprises. (A Bachelor's Dissertation, JAMK University of Applied Sciences).

West, M. A. and Farr, J. L. (1989). Innovation at work: Psychological perspectives. Social Behavior, 4(1): 15-30.

Widmann, A. and Mulder, R. H. (2018). Team learning behaviors and innovative work behavior in work teams. European Journal of Innovation Management, 21(3): 501-20.

Yidong, T. and Xinxin, L. (2013). How ethical leadership influence employees' innovative work behavior: A perspective of intrinsic motivation. Journal of Business Ethics, 116(2): 441-55. 